\title{
Effect of Replacement of Cement \& Aggregate by Glass Powder \& Recycled Aggregate on Flexural Strength of Concrete
}

\author{
Raju Prajapati ${ }^{1}$, Chaitanya Mishra ${ }^{2}$ \\ ${ }^{1}$ Student \\ ${ }^{2}$ Guide
}

\begin{abstract}
Concrete is the most widely used man made construction material in the world. The popularity of concrete is due to the fact that from the common ingredients the properties of concrete are tailored to meet the demand of any particular application and then most widely used in all types of civil engineering works including infrastructures, low and high rise buildings, defense developments. It is obtained by mixing cementing materials, water and aggregate. However in recent years the wisdom of own continued wholesale extraction and use of aggregate from natural resources has been questioned at on international level. This is mainly because of the depletion of quality primary aggregate and greater awareness of environmental protection. In light of this the availability of natural resource to future generations has also been realized. In fact many governments throughout the world have now introduced various measures aimed at reducing the use of primary aggregates and increasing reuse and recycling where it is technically, economically or environmentally acceptable. The project explores a theme on the need for recycled aggregates and highlights its potential use as aggregate in new concrete construction. Research comprises of studies on offer of replacement of cement \& aggregate by glass powder and recycled aggregate in concrete by some percentage for 28 days flexural strength of concrete. a result show that the flexural strength of modified concrete gives higher result $\left(7.11 \mathrm{~N} / \mathrm{mm}^{2}\right)$ with $5 \%$ glass powder \& slightly lower result $\left(6.50 \mathrm{~N} / \mathrm{mm}^{2}\right)$ with $10 \%$ glass powder where as recycled aggregate percentage is fixed at 20
\end{abstract}

Keywords: controlled concrete, modified Concrete, Flexural Strength, Natural Aggregates (N.A), Recycled Aggregate (R.A), Glass powder (G.P.),Mean strength (M.S.)

\section{Introduction}

Concrete industry or construction industry uses billion tons of raw materials each year, is the largest user of natural resources in the world. The impact on environment from the production of raw materials of concrete (such as cement and fine and coarse aggregates) is considerable. The scale of the problem makes it prudent to investigate other sources of raw materials in order to reduce the consumption of energy and available natural resources

Waste arising from construction and demolition constitutes one of the largest waste streams within the country. Of this a large proportion of potentially useful material disposed of as landfill. The environmental and economic implications of this are no longer considered sustainable and, as a result, the construction industry is experiencing more pressure than ever before to overcome this practice. On the other hand, in recent years the wisdom of continued wholesale extraction and use of aggregates from natural resources has been questioned at an international level. This is mainly because of the depletion of quality primary aggregates and greater awareness of environmental protection. The results of an extensive experimental programme aimed at examining the performance of Portland-cement.

Concrete produced with natural and coarse recycled aggregates. The effects of coarse recycled concrete aggregate on a range of fresh, engineering and durability properties have been established and assessed its suitability for use in a series of designated applications. Sustainable construction is a widely used concept now. It was introduced due to the growing concern about future of the planet, and it applies specifically for construction industry as, this being a huge consumer of natural resource. In addition to the 1.6 billion tons of cement used worldwide, the concrete industry is consuming 10 billion tons of sand and rock, and 1 billion tons of mixing water annually. In short the concrete industry, which uses 12.6 billion tons of raw materials each year, is the largest user of natural resources in the world. It's the world's most widely used construction material, but at the same time it is not an environmentally friendly material too. On the out-source when a building is demolished after its use, for repairs or for deterioration it generates large amount of waste streams, which conventionally and till today is used for land filling. In recent years, the recyclable potential of construction and demolition waste has made it a target of interest and the main focus of waste management policies on encouraging minimization, reuse, recycling, and valorization of the waste as opposed to its final disposal in landfills. The increasing trend of land filling and the scarcity of natural aggregates on other hand encourage the use of waste from the construction sites as a source for aggregate.

\section{Objective}

- To determined the best combined of recycled aggregate and glass powder by replacing aggregate and cement content at which concrete shows its high flexural strength and durability of concrete with economical construction material.

\section{Scope of the Work}

As India is a fast growing and developing country all over networks of road ways is developing at a fast rate due to 


\section{International Journal of Science and Research (IJSR) \\ ISSN (Online): 2319-7064}

Index Copernicus Value (2013): 6.14 | Impact Factor (2014): 5.611

which old structures are being demolished in order to widening of roads \& construction of sewage conveyance lines Due to this use of natural resources like natural aggregates has increased to a great extent. now due to demolishing of old structures we are getting large amount of demolished concrete which can be recycled in form of aggregates and can be used in replacement of natural aggregate.

It is recommended for future studies that the resource on use of glass powder is required to extend to a wider perspective in order to know the actual behavior and effective utilization of glass powder and recycled aggregate which gives an idea to study more parameters and different governing effect of glass powder on engineering properties of fresh and hardened concrete hence future work can be extended as follow

- The durability test can be conducted to know the long term effect of glass powder and recycled aggregate in concrete.

- To know the effect of different type of glass powder on concrete strength.

- To know the exact reason behind the increment in strength of concrete and bond strength between inter-materials and between materials and steel.

\section{Methodology}

Methodology behind the research is as follows:

\section{Specification of Materials}

\section{Natural Aggregates (N.A)}

Natural aggregates consists of rock fragments that are used in their natural state ,or are used after mechanical processing such as crushing, washing and sizing. Coarse aggregates are used with size between $20 \mathrm{~mm}-4.75 \mathrm{~mm}$. Crushed stone and sand and gravel are the two primary sources of natural aggregate, which are used directly in construction or as a raw material for construction products such as concrete and bituminous road materials

\section{Recycled Aggregates (R.A.)}

Recycled aggregates maximum size up to $25 \mathrm{~mm}$ are aggregates derived from the processing of materials previously used in a product and/or in construction. Examples include recycled concrete from construction and demolition waste material.

\section{Glass powder}

Glass powder is the waste product which can be obtained after cutting of glass product or also derived from grounding the waste glass material to fine powder. The glass powder from glass manufacturing industries can also be obtained in bulk amount which have same fineness modulus of cement.

\section{Cement}

Portland cement grade 43 is the most common type of cement in general usage .Cement is a most important constituent in concrete and well known binding material has occupied an indispensable place in the construction work. . For ordinary Portland cement, the residue by mass in 90 micron sieve should not exceed 10 percent. The standard cement should comply with the following conditions of fineness as given by IS: 460-1978 \& IS: 269-1976.

\section{Sand}

A loose granular substance, typically pale yellowish brown, resulting from the erosion of siliceous and other rocks and forming a major constituent of beaches, river beds, the seabed, and deserts. Natural sand is provided with maximum size of $4.75 \mathrm{~mm}$.

\section{Water}

Water is very actively participated in the chemical reaction with cement. Since it helps to form the strength giving cement gel, the quantity and quality of water is required to be looked into very carefully and secondly it acts as a lubricant of all other material and make concrete workable.

\section{Preparation of Specimen}

One control mix named as controlled concrete and 16 experimental mixes named as modified concrete were prepared in corporating the glass powder and recycled aggregate in concrete mix by partial replacement of cement and aggregate respectively for each combination three beam were casted for 7 days testing and three beam were casted for 28 days testing. Beam were casted for flexural strength test. That means to 51 beams (48 modified beams +3 normal concrete beams) are prepared for 7 days testing and similarly 51 beams are prepared for 28 days testing hence total 102 specimen were prepared.

Mix proportion :- 1:1.004:2.332

\section{Curing of Specimen}

After 24 hours of casting the specimen are removed from the mould and immediately submerged in clean fresh water and kept there until taken out just prior to test. The water in which the specimen are submerged are renewed every seven days. The specimen are not to be allowed to become dry at any time until they have been tested.

\section{Flexural Strength}

Flexural strength is one measure of the tensile strength of concrete. It is a measure of a concrete beam or slab resist failure in bending the flexural strength is expressed as modules of repture (M.R.) in measured Psi (mpa).

Flexural strength is checked after 7 and 28 days curing of beam for both controlled concrete \& modified concrete. The specimen are tested in universal testing machine with 2 ton load carrying capacity as per IS : 516-1959 (2004)

By this comparison of flexural strength we have accessed the effect of glass powder and recycled aggregate on the flexural strength of concrete.

\section{Result}

To estimate flexural strength of controlled concrete and modified concrete mix, beams are prepared for both the concrete mix flexural strength test has given following results 


\section{International Journal of Science and Research (IJSR)}

ISSN (Online): 2319-7064

Index Copernicus Value (2013): 6.14 | Impact Factor (2014): 5.611

\begin{tabular}{|c|c|c|c|}
\hline Type of Mix & \multicolumn{3}{|c|}{ Flexural strength in $\mathrm{N} / \mathrm{mm}^{2}$} \\
\hline controlled concrete & 6.680 & 6.680 & 6.660 \\
\hline M.S. & \multicolumn{3}{|c|}{6.670} \\
\hline GP05RA05 & 5.070 & 5.020 & 5.090 \\
\hline M.S. & \multicolumn{3}{|c|}{5.060} \\
\hline GP05RA10 & 5.190 & 5.170 & 5.090 \\
\hline M.S. & \multicolumn{3}{|c|}{5.170} \\
\hline GP05RA15 & 6.670 & 6.690 & 6.650 \\
\hline M.S. & \multicolumn{3}{|c|}{6.670} \\
\hline GP05RA20 & 6.900 & 7.310 & 7.120 \\
\hline M.S. & \multicolumn{3}{|c|}{7.110} \\
\hline GP10RA05 & 5.180 & 4.220 & 6.050 \\
\hline M.S. & \multicolumn{3}{|c|}{5.150} \\
\hline GP10RA10 & 5.740 & 6.010 & 5.830 \\
\hline M.S. & \multicolumn{3}{|c|}{5.860} \\
\hline GP10RA15 & 6.480 & 7.710 & 5.070 \\
\hline M.S. & \multicolumn{3}{|c|}{6.420} \\
\hline GP10RA20 & 6.580 & 6.430 & 6.490 \\
\hline M.S. & \multicolumn{3}{|c|}{6.500} \\
\hline GP15RA05 & 5.290 & 5.270 & 5.220 \\
\hline M.S. & \multicolumn{3}{|c|}{5.260} \\
\hline GP15RA10 & 6.200 & 6.270 & 6.250 \\
\hline M.S. & \multicolumn{3}{|c|}{6.240} \\
\hline GP15RA15 & 6.210 & 6.290 & 6.400 \\
\hline M.S. & \multicolumn{3}{|c|}{6.300} \\
\hline GP15RA20 & 6.270 & 5.200 & 5.900 \\
\hline M.S. & \multicolumn{3}{|c|}{5.790} \\
\hline GP20RA05 & 5.000 & 5.890 & 5.100 \\
\hline M.S. & \multicolumn{3}{|c|}{5.330} \\
\hline GP20RA10 & 6.000 & 7.110 & 6.900 \\
\hline M.S. & \multicolumn{3}{|c|}{6.670} \\
\hline GP20RA15 & 5.560 & 6.200 & 6.900 \\
\hline M.S. & \multicolumn{3}{|c|}{6.220} \\
\hline GP20RA20 & 5.800 & 5.190 & 5.000 \\
\hline M.S. & \multicolumn{3}{|c|}{5.330} \\
\hline
\end{tabular}

our experimental study basis $5 \%$ glass powder will provide higher flexural strength( $7.11 \mathrm{~N} / \mathrm{mm}^{2}$ \& $10 \%$ provide slightly lower result $(6.50 \mathrm{~N} / \mathrm{mm})^{2}$, keeping $\%$ of recycled aggregate at 20 .

\section{References}

[1] Dhanraj Mohan Patil, Dr. Keshav K.Sangle, "Experimental Investigation of Waste Glass Powder As Partial Replacement of Cement in Concrete", International Journal of Advanced Technology in Civil Engineering, ISSN: $2231-5721$, Volume-2, Issue-1, 2013

[2] R.Vandhiyan, K. Ramkumar, R. Ramya, "Experimental Study on Replacement Of Cement By Glass Powder", International Journal of Engineering Research \& Technology (IJERT), Vol. 2 Issue 5, May - 2013.

[3] Dr. G.Vijayakumar, Ms H. Vishaliny, Dr. D. Govindarajulu, "Studies on Glass Powder as Partial Replacement of Cement in Concrete Production", International Journal of Emerging Technology and Advanced Engineering, Volume 3, Issue 2, February 2013.

[4] Dr.B.R.Patagundi, Dr.K.B.Prakash, "Effect of Temperature On The Properties Of Concrete Containing Glass Powder As Pozzolana", International Journal of Engineering Research \& Technology (IJERT), Vol. 1 Issue 8, October -2012.

[5] Krishnakumar S. *1, Anju Sam2a,Jayasree S.2c and Job Thomas1c Bond strength of concrete containing crushed concrete aggregate, Cochin University of Science and Technology, Kochi-682022,Kerala,, India.

[6] Prof. Chetna M Vyas Prof. (Dr.) Darshana R Bhatt Use of Recycled Coarse Aggregate in ConcreteNew VallabhVidhyanagar - Gujarat - India.

[7] Shetty M.S. "concrete technology" Theory and Practice, the English language book of S.Chand Publication.

[8] IS 10262:2009 Concrete mix Proportioning- Guidelines

[9] IS: 8112 - 198943 grade ordinary Portland cementspecification.

[10] IS: 383-1997 specification for coarse and fine aggregates from natural sources for concrete.

[11] IS: 456-2000 Plain \& reinforced concrete

[12]IS: 516-1959 Indian Standard, Methods of tests for strength of concrete.

Flexural strength of concrete in 28-days at 5\%,10\%, 15\%, and $20 \%$ constant of glass powder

\section{Conclusion}

Studies on effect of glass powder and recycled aggregate on controlled concrete gave the conclusion that with $20 \%$ constant recycled aggregate in association with $5-10 \%$ glass powder will provide very good flexural strength precisely on 